\title{
Food deprivation is integral to the 'hand to mouth' existence of homeless youths in Toronto
}

\author{
Valerie Tarasuk ${ }^{1, *}$, Naomi Dachner ${ }^{1}$, Blake Poland ${ }^{2}$ and Stephen Gaetz ${ }^{3}$ \\ 'Department of Nutritional Sciences, Faculty of Medicine, University of Toronto, Toronto, Ontario, Canada M5S \\ 3E2: ${ }^{2}$ Department of Public Health Sciences, University of Toronto, Toronto, Ontario, Canada: ${ }^{3}$ Faculty of \\ Education, York University, Toronto, Ontario, Canada
}

Submitted 31 January 2008: Accepted 28 October 2008: First published online 15 January 2009

\begin{abstract}
Objective: To describe homeless youths' experiences of food insecurity and examine the relation between chronic food deprivation and food acquisition practices.

Design: A cross-sectional survey of homeless youths was conducted in 2003 to assess their nutritional vulnerability and describe their food acquisition practices. Setting: Toronto, Canada.

Subjects: Two hundred and sixty-one youths, aged 16-24 years, who had spent ten or more of the past thirty nights sleeping in a temporary shelter, public space or friend's place, because they had no place of their own. Most participant recruitment (70\%) occurred outdoors, but $30 \%$ were recruited in drop-in centres. Results: Over the past $30 \mathrm{~d}, 28 \%$ of males and $43 \%$ of females experienced chronic food deprivation (i.e. reduced food intake for $\geq 10 \mathrm{~d}$ ), and $32 \%$ of females and $48 \%$ of males reported problems obtaining water to drink. Most youths routinely obtained meals at charitable programmes and panhandled for money for food, and many routinely stole food or ate day-old food obtained from restaurants. In contrast, eating food discarded by others and postponing debt payments were strategies of desperation, more common among youths experiencing chronic food deprivation. Additionally, for males, deliberately seeking the company of friends, relatives or acquaintances to obtain food, and for females, borrowing money or trading sex for food, were associated with chronic food deprivation.

Conclusions: The pervasiveness and severity of food insecurity experienced by the youths and their desperate means of food acquisition highlight the need for more effective responses to the plight of homeless youths in Canadian cities.
\end{abstract}

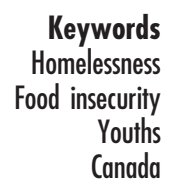

With homelessness recognized as a growing problem in many developed countries, 'the homeless' have become an increasing focus of nutrition research and intervention. Problems of insufficient food access ${ }^{(1-6)}$ and nutritional vulnerability $^{(7-15)}$ have been documented among homeless groups in many affluent Western nations. Ethnographic research findings suggest that homeless individuals live a 'hand to mouth' existence, locked in a daily struggle to meet their immediate needs for food and shelter ${ }^{(16-18)}$. Their nutritional vulnerability has been linked to the inadequacy of meals served in soup kitchens or shelters ${ }^{(2,7,8,11,19)}$, but there has been little examination of the role of other food acquisition strategies.

In 2003, we undertook a study of 261 homeless youths in Toronto to characterize the extent and nature of their nutritional vulnerability ${ }^{(14,20,21)}$. Most youths interviewed existed outside the 'social safety net', obtaining money through the informal (and often illegal) economy and living in public spaces. Dietary assessments (results of which have been reported elsewhere) indicated that most had inadequate intakes of folate, vitamin A, vitamin $\mathrm{C}, \mathrm{Zn}$ and $\mathrm{Mg}$; additionally, more than half of the young women in the sample had inadequate intakes of $\mathrm{Fe}$ and vitamin $\mathrm{B}_{12}{ }^{(14)}$. Here we examine the relationship between chronic food deprivation and food acquisition practices among this sample to gain a fuller understanding of their vulnerability.

\section{Methods}

\section{Sampling and data collection}

Data collection occurred between April and October 2003. Youths were eligible to participate if they were: (i) 16-24 years of age; (ii) not pregnant; and (iii) without stable, secure housing arrangements, defined as having spent ten or more of the past thirty nights sleeping in a 
temporary shelter, indoor or outdoor public space, or friend's place, because they had no place of their own. Six drop-in centres and twenty-eight outdoor locations where homeless youths 'hung out' (e.g. under bridges, in abandoned buildings, parks, garages) in downtown Toronto were identified as recruitment sites. Drop-in centre workers were contacted to obtain estimates of the number of eligible youths using their facilities, and field observations were conducted to estimate the number of homeless youths in each outdoor area. Quotas proportional to these estimates were developed for each site, assuming a target sample of 240 youths (120 male, 120 female). Because the number of homeless youths in any location at any time was relatively small, random sampling was not feasible. Instead, interviewers systematically approached each youth they encountered at each site. Of the 483 youths approached, 170 were deemed ineligible ( $68 \%$ because they failed to meet the criteria for unstable housing, $24 \%$ because they were over 24 years of age, $4 \%$ because they were pregnant, $4 \%$ for other reasons), forty declined to participate and twelve were subsequently dropped from the study (eleven because they were found to be duplicates and one because of data quality concerns). A final sample of 261 youths was achieved, reflecting an $83 \%$ participation rate. Seventy per cent of the final sample was recruited from outdoor locations.

Participants were interviewed when recruited and the time and location for a second interview was arranged. One hundred and ninety-five participants (75\%) completed second interviews, and $91 \%$ of these occurred within $14 \mathrm{~d}$ of the first interview. Both interviews included a multi-pass $24 \mathrm{~h}$ dietary intake recall, but the first interview also included an interviewer-administered questionnaire designed to capture sociodemographic characteristics, living circumstances over the past $30 \mathrm{~d}$, frequency of alcohol and drug use over the past $30 \mathrm{~d}$, food security, food acquisition strategies, and strategies used to obtain water to drink. Food security was assessed using the 30-d Food Security Module and a 6-month measure adapted from the Household Food Security Survey Module ${ }^{(22)}$.

From a review of earlier studies of homeless youths in Canada ${ }^{(16,17,23-26)}$, we identified five means of food acquisition common among this group: (i) purchasing food with money obtained through activities like panhandling; (ii) obtaining food from other people (passersby or those with whom they had some relationship); (iii) obtaining food free of charge or at nominal cost from charitable meal programmes; (iv) stealing food; and (v) retrieving food that had been discarded by others. To characterize participants' use of charitable meal programmes, we asked how often in the past $7 \mathrm{~d}$ they had obtained meals from a soup kitchen, drop-in centre, shelter or mobile van (the primary routes through which food assistance is dispensed to homeless individuals in Toronto). To determine their use of other strategies, we developed a series of closed-ended questions to ask how often over the past $30 \mathrm{~d}$ they had engaged in specific activities to get food when they had no food or money for food; frequency was recorded as 'never, 'sometimes' or 'often'. The questionnaire was pilot-tested on a sample of twenty-five homeless youths to ensure the acceptability and comprehensibility of all items.

\section{Data analysis}

All statistical analyses were conducted using the SAS/PC statistical software package version 9.1 (SAS Institute, Cary, NC, USA).

To classify food security status over 6 months, we applied the thresholds used to classify adult food insecurity in US population surveys ${ }^{(22,27)}$. Food security over the previous $30 \mathrm{~d}$ was assessed in terms of chronic food deprivation, defined as reporting three or more of five conditions (i.e. skipped meals, ate less than you felt you should, felt hungry but did not eat, cut the size of meals, went a whole day without eating) for $\geq 10 \mathrm{~d}$ during this period.

Logistic regression was used to compare food security prevalence rates by gender and identify personal characteristics associated with chronic food deprivation over the past $30 \mathrm{~d}$, considering age ( $<19$ years, $\geq 19$ years), duration of homelessness ( $<1$ year, $\geq 1$ year), education (completion of grade 12 or not), frequent drug use (defined as using crack, cocaine, speed/crystal, opiates, glue, gasoline, tranquilizers, hallucinogens or ecstasy every day or several times per week) over the past $30 \mathrm{~d}$, and consumption of alcohol every day or several times per week over the past $30 \mathrm{~d}$. Logistic regression was also used to examine the association between chronic food deprivation and reported problems obtaining water to drink, the frequency of programme use (considering both rare $(\leq 2 \mathrm{~d})$ and frequent $(6-7 \mathrm{~d})$ use over the past $7 \mathrm{~d}$ ) and the frequent use of other specific food acquisition strategies (defined as 'often' using the strategy in the past $30 \mathrm{~d}$ ). Because youths' food acquisition patterns and experiences of chronic food deprivation differed by gender, all analyses were stratified.

\section{Results}

Sample characteristics are summarized in Table 1. Almost all youths were food-insecure over the past 6 months and most experienced severe food insecurity (Table 2). Over the past $30 \mathrm{~d}, 43 \%$ of females and $28 \%$ of males experienced chronic food deprivation. Severe food insecurity and chronic food deprivation were more prevalent among females.

Chronic food deprivation appeared unrelated to youths' age or education level (data not shown). There was also no relationship between the duration of homelessness and chronic food deprivation among males (OR $=1 \cdot 59,95 \%$ CI $0 \cdot 77,3 \cdot 38)$, but the odds of chronic 
food deprivation among females who had been homeless for a year or more was $2 \cdot 87$ (95\% CI 1·32, 6.23) compared with those who became homeless more recently. Females who reported consuming alcohol daily or almost daily had higher odds of chronic food deprivation $(\mathrm{OR}=2 \cdot 26$, $95 \%$ CI $1 \cdot 05,4 \cdot 86)$, but no similar association was

Table 1 Sociodemographic characteristics and present circumstances (\%): homeless youths, Toronto, Canada, 2003

\begin{tabular}{|c|c|c|}
\hline & $\begin{array}{l}\text { Males } \\
(n \text { 149) }\end{array}$ & $\begin{array}{l}\text { Females } \\
(n 112)\end{array}$ \\
\hline \multicolumn{3}{|l|}{ Age } \\
\hline $16-18$ years & 20 & 38 \\
\hline $19-24$ years & 80 & 62 \\
\hline \multicolumn{3}{|l|}{ Ethno-racial identity } \\
\hline White & 84 & 77 \\
\hline Black (African/Caribbean) & 6 & 5 \\
\hline First Nations, Inuit, Metis, Other Aboriginal & 7 & 13 \\
\hline Other (Asian, Latin American, etc.) & 3 & 5 \\
\hline \multicolumn{3}{|l|}{ Education* } \\
\hline Grade 8 & 14 & 13 \\
\hline Grade 9-11 & 63 & 71 \\
\hline Grade 12 or more & 24 & 16 \\
\hline \multicolumn{3}{|l|}{ Time since leaving home } \\
\hline 2 months & 12 & 18 \\
\hline 3-6 months & 11 & 18 \\
\hline $7-12$ months & 8 & 8 \\
\hline$>12$ months & 68 & 56 \\
\hline \multicolumn{3}{|l|}{ Place where previous night had been spent } \\
\hline Outdoors & 56 & 67 \\
\hline Friend's place & 21 & 22 \\
\hline Squatt & 8 & 4 \\
\hline Shelter & 8 & 4 \\
\hline Other $\ddagger$ & 7 & 3 \\
\hline \multicolumn{3}{|l|}{ Main source of income in past $30 \mathrm{~d} \S$} \\
\hline Panhandling or squeegeeingll & 56 & 54 \\
\hline Theft or drug trade work & 22 & 13 \\
\hline Sex trade work & 6 & 19 \\
\hline Government transfers & 7 & 3 \\
\hline Selling items (handicrafts, etc.) & 4 & 4 \\
\hline Money from family or friends & 3 & 4 \\
\hline Paid employment & 1 & 4 \\
\hline \multicolumn{3}{|l|}{ Frequent heavy drug use in past $30 \mathrm{~d}$} \\
\hline Yes & 34 & 45 \\
\hline No & 66 & 55 \\
\hline \multicolumn{3}{|l|}{$\begin{array}{l}\text { Consumption of alcohol every day or several } \\
\text { times per week in past } 30 \mathrm{~d}\end{array}$} \\
\hline Yes & 48 & 43 \\
\hline No & 52 & 57 \\
\hline
\end{tabular}

*Generally, youths in Canada complete Grade 12 at the age of 18 years. †'Squats' are makeshift shelters in abandoned buildings.

łIncluded jail, Internet café, bath house, hotel, 'with client' and 'own place'. $\S$ Two males reported no source of income.

IIThe practice of washing the windows of vehicles stopped at intersections and then asking motorists for money. observed for males (OR $=1 \cdot 39$, 95\% CI $0 \cdot 68,2 \cdot 87)$. Frequent heavy drug use was not associated with chronic food deprivation (males: $\mathrm{OR}=1 \cdot 15,95 \% \mathrm{CI} 0 \cdot 55$, 2.45; females: $\mathrm{OR}=0 \cdot 81,95 \%$ CI $0 \cdot 38,1 \cdot 72$ ).

Thirty-two per cent of females and $48 \%$ of males reported problems obtaining drinking water. For males, this was positively associated with chronic food deprivation $(\mathrm{OR}=2 \cdot 13,95 \% \mathrm{CI} 1 \cdot 01,4 \cdot 51)$, but no significant association was observed for females (OR $=1 \cdot 46,95 \%$ CI $0 \cdot 69$, $3 \cdot 11$ ). The most commonly reported sources of drinking water were fast-food restaurants and washrooms (Table 3).

\section{Relationship between chronic food deprivation and food acquisition strategies}

In the past $7 \mathrm{~d}, 87 \%$ of males and $89 \%$ of females had made at least some use of charitable meal programmes, with drop-in centres the most common source of meals (Table 4). The frequency with which youths used meal programmes was unrelated to their experiences of chronic food deprivation.

When they needed food over the past $30 \mathrm{~d}$, almost three-quarters of youths panhandled and about half stole food, but neither strategy was associated with chronic food deprivation for males or females (Table 5). Over the past $30 \mathrm{~d}, 44 \%$ of males and $47 \%$ of females had borrowed money from someone to buy food; the median amount of money borrowed was CAN\$ 15.00. The behaviour was associated with chronic food deprivation for females (OR $=2 \cdot 18,95 \%$ CI $1 \cdot 02,4 \cdot 68)$, but not males ( $\mathrm{OR}=2 \cdot 01,95 \% \mathrm{CI} 0 \cdot 97,4 \cdot 16)$. Further indication of the pervasive vulnerability associated with indebtedness came from youths' reports of putting off paying for other things as a way to free up money for food. Almost half reported such behaviours in the past $30 \mathrm{~d}$, and youths who often postponed payments had significantly higher odds of chronic food deprivation (Table 5).

Approximately half of the youths surveyed had eaten food discarded by others, and almost half reported getting free day-old food from fast-food establishments at some point in the last $30 \mathrm{~d}$. The latter strategy was not linked to chronic food deprivation but, for both males and females, the odds of reporting often eating discarded food increased if they had experienced chronic food deprivation over this same period (Table 5).

Table 2 Food security status over past 6 months and past $30 \mathrm{~d}$ (\%): homeless youths, Toronto, Canada, 2003

\begin{tabular}{|c|c|c|c|c|}
\hline & \multirow[b]{2}{*}{ Males ( $n$ 149) } & \multirow[b]{2}{*}{ Females (n 112) } & \multicolumn{2}{|c|}{ Comparison, males $v$. females } \\
\hline & & & OR & $95 \% \mathrm{Cl}$ \\
\hline \multicolumn{5}{|c|}{ Food security over past 6 months } \\
\hline Food secure & 9 & 6 & 1.00 & \\
\hline Moderately food insecure & 18 & 9 & 1.00 & \\
\hline Severely food insecure & 73 & 85 & $2 \cdot 05$ & $1 \cdot 09,3 \cdot 85$ \\
\hline \multicolumn{5}{|c|}{ Chronic food deprivation over past $30 \mathrm{~d}$} \\
\hline Yes & 28 & 43 & $1 \cdot 98$ & $1 \cdot 18,3 \cdot 32$ \\
\hline No & 72 & 57 & 1.00 & \\
\hline
\end{tabular}


Table 3 Reported sources of drinking water*: homeless youths, Toronto, Canada, 2003

\begin{tabular}{lcc}
\hline & \multicolumn{2}{c}{ Proportion reporting source $(\%)$} \\
\cline { 2 - 3 } Source & Males $(n$ 149) & Females $(n$ 111)+ \\
\hline Fast-food restaurants, coffee/doughnut shops & 36 & 46 \\
Washrooms (in food outlets and public places) & 32 & 43 \\
Public drinking fountains & 36 & 24 \\
Other people (friends or acquaintances) & 28 & 30 \\
Social service agencies (e.g. drop-in centres, outreach vans) & 17 & 36 \\
Purchased bottled water & 22 & 27 \\
Outdoor locations (e.g. lawn-watering devices, outdoor taps at gas stations, & 13 & 10 \\
private residences) & & \\
\hline
\end{tabular}

*Because respondents could report more than one source, values do not add to $100 \%$.

tData missing for one female.

Table 4 Frequency of meal acquisition from charitable food assistance programmes over past $7 \mathrm{~d}$ : homeless youths, Toronto, Canada, 2003

\begin{tabular}{|c|c|c|c|c|c|}
\hline \multirow{2}{*}{$\begin{array}{l}\text { Number of days in last } 7 d \\
\text { when } \geq 1 \text { meal was obtained }\end{array}$} & \multicolumn{5}{|c|}{ Proportion reporting use (\%) } \\
\hline & Shelters & Soup kitchens & Outreach vans & Drop-in centres & Any programme \\
\hline \multicolumn{6}{|l|}{ Males (n 149) } \\
\hline Never & 83 & 62 & 51 & 32 & $13+$ \\
\hline $1-2 d$ & 8 & 19 & 28 & 29 & $27 \dagger$ \\
\hline $3-5 d$ & 3 & 10 & 13 & 32 & 38 \\
\hline $6-7 d$ & 7 & 9 & 9 & 7 & $21 \ddagger$ \\
\hline \multicolumn{6}{|l|}{ Females $(n 111)^{*}$} \\
\hline Never & 86 & 73 & 39 & 25 & $11+$ \\
\hline $1-2 d$ & 6 & 18 & 33 & 24 & $22+$ \\
\hline $3-5 d$ & 4 & 8 & 24 & 46 & 57 \\
\hline $6-7 d$ & 3 & 1 & 4 & 5 & $11 \ddagger$ \\
\hline
\end{tabular}

*Missing responses for one female.

tThe odds of chronic food deprivation in the past $30 \mathrm{~d}$ for youths who used programmes $0-2 \mathrm{~d}$ was $1 \cdot 85(95 \% \mathrm{Cl} 0 \cdot 70,4 \cdot 89)$ for males and $0 \cdot 33$ $(95 \% \mathrm{Cl} 0.09,1 \cdot 18)$ for females, compared with other youths.

$\ddagger$ The odds of chronic food deprivation in the past $30 \mathrm{~d}$ for youths who used programmes $6-7 \mathrm{~d}$ was $0.54(95 \% \mathrm{Cl} 0.21,1.43)$ for males and 3.00 $(95 \% \mathrm{Cl} 0.85,10 \cdot 6)$ for females, compared with other youths.

At times when they needed food, it was not uncommon for youths to seek out the company of others who could provide it. Approximately half of the youths reported going to a friend or relative's place to eat, and one-quarter of youths reporting 'hanging out' with people just because they had food (Table 5). The frequent use of these strategies was associated with chronic food deprivation for males but not females. Eleven per cent of males and $23 \%$ of females had exchanged sex for food or money for food in the past $30 \mathrm{~d}$, but the frequent use of this strategy was associated with chronic food deprivation only among females (Table 5).

\section{Discussion}

The present study of homeless youths was undertaken to characterize the extent and nature of their nutritional vulnerability. The portrayal of food insecurity that emerges from our research differs markedly from the phenomenon commonly assessed among domiciled groups. The youths reported much higher levels of food deprivation than are typically observed in general population surveys ${ }^{(28)}$, highlighting the extreme vulnerability that comes with homelessness and the abject poverty that underscores this condition.

In addition to problems of food deprivation, many youths reported problems accessing drinking water. Similar findings emerged from a recent study of streetbased sex workers in Miami ${ }^{(29)}$. Without housing and with insufficient funds to purchase bottled water, homeless people are forced to rely on public sources of water or negotiate access to private supplies. In urban settings such as Toronto, access to public washrooms and drinking fountains has become increasingly limited because of concerns about cost and liability. Thus inadequate and insecure access to drinking water is an added dimension of food insecurity among homeless populations.

The ways in which homeless youths endeavoured to manage their food needs reflect a 'hand to mouth' existence, characterized by the use of a wide diversity of strategies to obtain small amounts of food for immediate consumption. Many of these strategies were stigmatizing and unsafe; some were illegal. Our examination of the relationship between youths' use of specific food acquisition strategies and their level of food deprivation suggests that some strategies such as eating food discarded by others are acts of extreme desperation, whereas other 
Table 6 Strategies employed to acquire food routinely or in times of desperation: homeless youths, Toronto, Canada, 2003

\begin{tabular}{|c|c|}
\hline Routine strategies & Desperate strategies* \\
\hline $\begin{array}{l}\text { Going to charitable meal } \\
\text { programmes }\end{array}$ & $\begin{array}{l}\text { Postponing payments of } \\
\text { debts, rent, etc. }\end{array}$ \\
\hline $\begin{array}{l}\text { Panhandling to get money } \\
\text { for food }\end{array}$ & $\begin{array}{l}\text { Eating food discarded by } \\
\text { others }\end{array}$ \\
\hline Stealing food & Males only: \\
\hline $\begin{array}{l}\text { Getting free day-old food } \\
\text { from restaurants }\end{array}$ & $\begin{array}{l}\text { Going to a friend or relative's } \\
\text { place for food } \\
\text { 'Hanging out' with someone } \\
\text { just because they have food } \\
\text { Females only: } \\
\text { Trading sex for food } \\
\text { Borrowing money for food }\end{array}$ \\
\hline
\end{tabular}

${ }^{*}$ Food acquisition strategies associated with significantly increased odds of chronic food deprivation over the past $30 \mathrm{~d}$.

behaviours like panhandling and stealing food are routine (Table 6). Although other researchers have not differentiated homeless youths' food acquisition behaviours in this way, the fact that similar behaviours have been reported by others ${ }^{(17,18,26)}$ suggests that our findings are characteristic of homeless youths in this country.

Although many youths in this study routinely used charitable meal programmes, this practice did not protect them from chronic food deprivation, nor did it obviate the need for them to acquire food in other ways as well. These findings highlight the need for a better 'safety net' to help youths meet their basic needs. In our qualitative research with homeless youths, they complained about the infrequent service, limited meal hours, and need to travel considerable distances to attend different charitable meal programmes at different times of the day or week ${ }^{(16,20)}$. Our subsequent inventory of local charitable food provisioning efforts (to be reported elsewhere) confirmed that meal services for those outside the shelter system are, for the most part, intermittent and uncoordinated, and the food served is generally of limited quantity and nutritional qual${ }^{\text {ity }}{ }^{(30)}$. While the establishment of ad hoc, charitable food programmes for homeless individuals is a strong testament to community concern and resourcefulness, our research results argue strongly for a more coherent response.

Our examination of youths' food acquisition strategies highlights the gendered nature of homelessness, a phenomenon documented elsewhere as well ${ }^{(5,24,26,31,32)}$. Other research with street youths has found that males generally earn more than females and are more likely to operate independently, whereas females tend to engage collectively, both in money-making and in living arrangements ${ }^{(24)}$. Consistent with this research, we found that using social relationships as a means to acquire food was routine for females, but such behaviour indicated desperation for males. None the less, female youths may engage more in high-risk, exploitive relationships, trading sex for food when they are desperate.

In conclusion, the pervasiveness and severity of food insecurity experienced by homeless youths in the present 
study and their desperate means of food acquisition highlight the urgent need for more effective responses to food insecurity among this group. While more work could be undertaken to improve youths' food access through charitable meal programmes in the community, we worry that this would amount to 'treating the symptom' rather than the problem. Homeless youths' food acquisition behaviours reflect the extreme desperation of their situations, providing a moral and public health imperative to find solutions to the problem of youth homelessness in Canadian cities.

\section{Acknowledgements}

The research was funded by an operating grant from the Canadian Institutes of Health Research (CIHR). In receiving this funding, the authors did not engage in any financial or other contractual agreements that caused or could be perceived to cause conflicts of interest. None of the authors has any other conflicts of interest to declare. All authors participated in the conceptualization of the research questions and study design, and aided in the interpretation of the results. V.T. conducted the statistical analysis and developed the manuscript. The authors are indebted to Mark Nord for assistance with the food security measure and to Tony Jinguang Li for preliminary data analysis.

\section{References}

1. Antoniades M \& Tarasuk V (1998) A survey of food problems experienced by Toronto street youth. Can J Public Health 89, 371-375.

2. Burt MR, Aron LY, Douglas T, Valente J, Lee E \& Iwen B (1999) Homelessness: Programs and the People they Serve. Washington, DC: The Urban Institute.

3. Children's Sentinel Nutrition Assessment Program (2005) Homelessness: Consequences for Young Children's Health and Nutrition. C-SNAP Brief. http://www.c-snap.org (accessed December 2005).

4. Gunderson C, Weinreb L, Wehler C \& Hosmer D (2003) Homelessness and food insecurity. J Housing Econ 12, 250-272.

5. Khandor E \& Mason K (2007) The Street Health Report 2007. Toronto: Street Health.

6. Whitbeck LB, Chen X \& Johnson KD (2006) Food insecurity among homeless and runaway adolescents. Public Health Nutr 9, 47-52.

7. Cohen BE, Chapman N \& Burt MR (1992) Food sources and intake of homeless persons. J Nutr Educ 24, 45S-51S.

8. Darmon N, Coupel J, Deheeger M \& Briend A (2001) Dietary inadequacies observed in homeless men visiting an emergency night shelter in Paris. Public Health Nutr 4 , $155-161$.

9. Evans NS \& Dowler EA (1999) Food, health and eating among single homeless and marginalized people in London. J Hum Nutr Diet 12, 179-199.

10. Gelberg L, Stein JA \& Neumann CG (1995) Determinants of undernutrition among homeless adults. Public Health Rep 110, 448-458.
11. Johnson LJ \& McCool AC (2003) Dietary intake and nutritional status of older adult homeless women: a pilot study. J Nutr Elder 23, 1-21.

12. Langnase K \& Mullis JM (2001) Nutrition and health in an adult urban homeless population in Germany. Public Health Nutr 4, 805-811.

13. Silliman K, Yamanoha MM \& Morrissey AE (1998) Evidence of nutritional risk in a population of homeless adults in rural Northern California. J Am Diet Assoc 98, 908-910.

14. Tarasuk V, Dachner N \& Li J (2005) Homeless youth in Toronto are nutritionally vulnerable. J Nutr 135, 1926-1933.

15. Wolgemuth JC, Myers-Williams C, Johnson P \& Henseler C (1992) Wasting malnutrition and inadequate nutrient intakes identified in a multiethnic homeless population. J Am Diet Assoc 92, 835-839.

16. Dachner N \& Tarasuk V (2002) Homeless 'squeegee kids': food insecurity and daily survival. Soc Sci Med $\mathbf{5 4}$, 1039-1049.

17. Hagan J \& McCarthy B (1997) Mean Streets: Youth Crime and Homelessness. Cambridge: Cambridge University Press.

18. Wingert S, Higgitt N \& Ristock J (2005) Voices from the margins: understanding street youth in Winnipeg. Can J Urban Res 14, 54-80.

19. Silliman K \& Wood S (2000) Evidence of nutritional inadequacy of meals served to homeless populations in rural northern California. Ecol Food Nutr 40, 285-297.

20. Gaetz S, Tarasuk V, Dachner N \& Kirkpatrick S (2006) 'Managing' homeless youth in Toronto. Can Rev Soc Policy 58, 43-61.

21. Li A, Dachner N \& Tarasuk V (2008) Food intake patterns of homeless youth in Toronto. Can J Public Health (In the Press).

22. Bickel G, Nord M, Price C, Hamilton WL \& Cook J (2000) Guide to Measuring Household Food Security. Washington, DC: US Department of Agriculture, Food and Nutrition Service, Office of Analysis, Nutrition and Evaluation.

23. Gaetz S \& O'Grady B (2002) Making money: exploring the economy of young homeless workers. Work Employ Soc 16, $433-456$.

24. Gaetz S (2004) Safe streets for whom? Homeless youth, social exclusion, and criminal victimization. Can J Criminol Criminal Justice 46, 423-455.

25. Baron SW (1989) Resistance and its consequences: the street culture of punks. Youth Soc 21, 207-237.

26. McCarthy B \& Hagan J (1992) Surviving on the street: the experiences of homeless youth. $J$ Adolesc Res 7, 412-430.

27. Nord M, Andrews M \& Carlson S (2006) Household Food Security in the United States, 2005. Washington, DC: US Department of Agriculture, Economic Research Service.

28. Health Canada (2007) Canadian Community Health Survey, Cycle 2.2, Nutrition (2004) - Income-Related Household Food Security in Canada. Ottawa: Office of Nutrition Policy and Promotion, Health Products and Food Branch, Health Canada.

29. Kurtz S, Surratt H, Kiley M \& Inciardi JA (2005) Barriers to health and social services for street-based sex workers. J Health Care Poor Underserved 16, 345-361.

30. Tse C \& Tarasuk V (2008) Nutritional assessment of charitable meal programmes serving homeless people in Toronto. Public Health Nutr 11, 1296-1305.

31. Ensign J \& Bell M (2005) Illness experiences of homeless youth. Qual Health Res 14, 1239-1254.

32. Roy E, Haley N, Lemire N, Boivin J, Leclerc P \& Vincelette J (1999) Hepatitis B virus infection among street youths in Montreal. Can Med Assoc J 161, 689-693. 